\title{
CRISIS REGULATION DEMAND
}

\author{
Mohammad Jaradat ${ }^{l}$ \\ Marius M. Motocu ${ }^{2}$
}

\begin{abstract}
This paper argues and identifies in its previous part the main hallmarks of the crisis as too-big-to-fail institutions that took on too much risk, insolvency resulting from contagion and counterparty risk, the lack of regulatory and supervisory integration, and the lack of efficient resolution regimes. Then this article looks at how the Basel III proposals address these issues, helping to reduce the chance of another crisis like the current one. The Basel III capital proposals have some very useful elements, notably a leverage ratio, a capital buffer and the proposal to deal with pro-cyclicality through dynamic provisioning based on expected losses. However, this article also identifies some major concerns.
\end{abstract}

Key words: crisis, capital buffer, leverage ratio, pro-cyclicality, liquidity coverage ratio.

JEL codes: G21.

\section{Introduction}

The losses in the market for subprime mortgages (subprime) United States were the catalyst for the current financial crisis. However, the poor quality of these loans, partially guaranteed, has long been known and defects on these claims widely anticipated. Therefore, why wait a shock that affects a small compartment in the U.S. mortgage market could become a major financial crisis, including causing the virtual collapse of the market for commercial paper (commercial paper) and market interchange, that is to say, markets generally considered the most liquid?

Banks transferred the credit risk to entities dedicated, called conduits, SIV (Special Investment Vehicles) or debt mutual funds (Special Purpose Vehicles). This practice gave the erroneous impression that the risk was out of the financial system. Experience has shown that this was not the case. The refinancing requirements resulting from the activation of particular lines of credit that banks were granted to these special purpose vehicles have reported tensions on the interbank market, requiring the intervention of central banks.

The origin of the current crisis seems of a more profound and structural. A broader perspective of recent changes observed in the capital markets to better understand their current momentum.

\section{The recent trends on financial market and liquidity}

\subsection{Disintermediation, financial liberalization, deregulation and securitization}

Disintermediation, deregulation and liberalization of financial and securitization are probably the most striking developments seen on the capital markets over the last decade. They not only profoundly changed the financial landscape but also the outline of liquidity.

Now, the banking system is the only one to provide credit and liquidity. Besides the traditional liquidity, as measured by the monetary aggregates and credit, develops a second component that depends on the amounts that nonbank financial intermediaries want an exchange. These two components have tended to evolve in parallel and, to some extent, reinforced

\footnotetext{
1 “Bogdan Vodă” University, Gr. Alexandrescu street, no. 26A, Cluj-Napoca, România, jaradat_hadi@ yahoo.com

${ }^{2}$ „Bogdan-Vodă” University, Gr. Alexandrescu street, no. 26A, Cluj-Napoca, România, mmotocu @ gmail.com.
} 
each other in recent years. Indeed, the strong growth of money supply and credit has been considered a key determinant of cheap financing conditions on capital markets. This funding is "easy" has another side, exacerbated the temptation for investors to take more risks and make greater use of debt, fueling the expansion of credit and currency.

The elimination of certain structural barriers between investment banking and bank deposits has also promoted the flow of credit, loan originators and issuers of debt securities. It has also resulted in increased competition within the financial sector and a stimulating financial innovation.

Finally, securitization has not only allowed banks to liquid financial assets, but they also offered new opportunities, granting of credits, their "re-packaging" and their sale as securities. In recent years, securitization has won almost all categories of claims.

\subsection{Emergence of a funding model called "initiation and distribution" of credit}

These trends have spawned a new model of risk transfer, in which banks, after granting loans, transfer the credit risk underlying a range of investors through dedicated instruments.

Previously, banks were the main initiators of the loans. They kept them on their balance sheet and followed them until maturity. Securitization has given them the opportunity to do more to show the credit risk on their balance sheet but to relocate to other investors. The steps that govern the granting of a loan as a mortgage have become very complexes. They are generally divided into several distinct activities, each of which may be exercised through institutions or different organisms. For example, the entire production process for a mortgage appealed to actors as diverse as the borrower, the originator (i.e. the bank), the arranger, which includes loans in the form of structured products, the Rating Agency, which issues a note to the latter, the lender relay, which temporarily provides loan servicing, asset manager and the collection agency mortgage. Credit risk is thus more widely distributed within the financial system. He was finally transferred to a large number of investors who are not only theoretically better equipped to live with and more willing to do so. In this context, the capital of banks can be used more efficiently, allowing, all things being equal, an increase in credit supply.

The gradual replacement of the securities to loans in bank assets has increased the sensitivity of bank balance sheets to valuation techniques. In fact, the recovery of complex structured instruments is a challenge. Due to existing international accounting standards (IFRS), the securities must be valued at fair value (fair value), that is to say, at market value (marked to market) or possibly as a function of a model (marked to model). However, most structured products which are not traded on secondary markets, they have not formally market price. To evaluate, finance companies typically use a combination of valuation models of credit risk, which occurs particularly in external ratings, and prices of products themselves illiquid.

\subsection{The main limitations of the previous funding model}

\section{The presence of imperfections in the credit market}

In this funding model, issuers of loans may be less incentive to ensure their sustainability as they plan to transfer credit risk to other investors. This moral hazard problem is even more profound when loans are granted by non-regulated. In the next step, the purchasers of loans, which are planning to restructure in the form of complex credit instruments, are reluctant to check the quality of the assets they have acquired. For they know that the end buyers rely primarily on the ratings assigned to the underlying asset. The information asymmetries affect so every step of the process. They also constitute a powerful source of contagion. Moreover, such a system can only work if each market participant involved in this process has ongoing access to liquidity. 


\section{Valuation}

By their nature, structured products are illiquid. They are made to fit perfectly to the characteristics and risk profile required by the purchaser. These properties limit their ability to be resold to other investors whose preferences or needs may be different. This indicates circularity: the valuation to fair value should be on the basis of market prices, under international accounting standards, operators cannot properly value an asset only if there sufficient liquidity in the market and, finally, the liquidity depend on the valuation.

In this process, the rating agencies are invested with a vital task to collect and monitor information on borrowers. This information is crucial to assess the risk and return of different assets and thus to facilitate the process of price formation. In addition, securitized markets, the rating system allows all stakeholders' access to information simple, clear and concise information on the credit risk associated with different classes and categories of financial instruments. The rating has become an integral part of the design and financial engineering of these products. The rating agencies determine the size of the slices and the levels of subordination of claims. They provide the methods and models for risk assessment and their correlation. They also impose conditions that purpose vehicles must necessarily be met in order to be able to issue securities. By allowing the comparability of structured products with a wide range of assets, they ensure their marketability or, to put it differently, their liquidity.

However, this process has two major weaknesses: first, the rating agencies consider themselves as solely responsible for the assessment of credit risk. Their ratings do not include the risk of liquidity as investors are convinced otherwise. Second, the model used to rate structured products is identical in terms of presentation, to that used for traditional bond products. But for investors, an AAA rating is traditionally associated with a stable investment. In addition, it seems that given the low yield of these products, investors have less incentive to analyze comprehensively the nature and sensitivity of these ratings. This behavior is probably not completely appropriate visà-vis the structured products whose ratings have shown a huge volatility, as we have seen recently.

\section{Uncertainties relating to the valuation of assets, the degree of risk exposure in general and in the counterparty risk in particular}

The diversity and complexity of the valuation techniques may lead to considerable variation in estimates of "fair value" among institutions. Consequently, a number of financial institutions have no clear idea of long-term performance of underlying loans. Furthermore, dilution of risk and complexity of structured products obscure the actual location of risk. Under these conditions, deterioration of the value of certain assets, as has been observed for sub-prime related assets, including securities backed by mortgages, may lead to increased uncertainty about the intrinsic value of many other categories of financial assets, whether or not ultimately exposed to subprime real estate market. This contrasts sharply with the standard model of bank intermediation where valuations of assets and credit are linked to fundamentals and carried at historical cost. In the context of securitization model, the problems of valuation may result in shortages of capital because of the recognition of "fair value". Indeed, fluctuations in asset prices are immediately reflected in banks' balance sheets.

\section{The relative inadequacy of capital at risk in the new model of securitization}

The new entities, such as conduits and SIVs, conducting, until recently, alterations maturity scale without any capital to absorb shocks. However, most of them were equipped with lines of credit or other guarantees of banks that sponsor. These credit lines will replace the capital that would otherwise have been required of these entities to issue commercial paper qualifying for the AAA rating. Securitization does not fully protect the banks credit risk on the assets transferred. Firstly, the originators of loans are usually exposed to the first defaults on loans they sell. During times of crisis, this exhibit reduced their profits and thus their own funds. Then, large 
amounts of instruments backed loans were acquired through conduit or SIV, which have large credit lines from banks that have set up specifically to address risks liquidity. As we have observed this summer, when the ducts are mobilizing their lines of credit, bank balance sheets can dramatically increase in times of crisis, reducing the amount of excess capital available to finance new loans.

\section{Implications and challenges for regulators}

\subsection{A shock from liquidity}

The combination of these four sources of fragility has been the cause of an abrupt change of regime, which made us move from a period of ample liquidity in an apparent shortage. Such a regime change is explained in various ways: first, by increasing the incertitude3. Due to the complexity of structured instruments and their rapid proliferation, market participants lack of historical references to evaluate and measure the behavior of these financial instruments in periods of crisis. The fact that AAA ratings have appeared less stable than what was normally expected in this asset class, with examples of downward revision of ratings of several levels in one day, has led investors to question the value All types of credit (not only mortgages).Accordingly, the incertitude may have led market participants to make decisions based on worst case scenarios. Although this behavior is rational to make robust decisions, the aggregation of rational individual decisions may have led to suboptimal macroeconomic results: market participants have liquidity have preferred to stay outside the market. Some have ceased to transact, considering that counterparty risk was considerably strengthened, while others preferred to hoard liquidity in a context of increased uncertainty regarding their own future needs of liquidity and degree of actual exposure to risks.

Second, disintermediation has resulted in increased competition among financial intermediaries, especially between banks and non-banks. The banks, however, retain an important role in channeling liquidity to sectors where it is needed most. They include access to central bank money. This may allow them to hoard liquidity injected by central banks and, in some cases, to exercise a rationing or liquidity pressures vis-à-vis its main competitors, particularly those without access to Central bank liquidity. In addition, banks have an interest in a context of asymmetric information, regardless of their competitive environment in their strategic choices of coverage. In such context, financial institutions can be encouraged to make tradeoffs in risk management. These tradeoffs can lead them to a waiting position vis-à-vis their competitors with limited reserves of liquidity. To the extent that the hedging strategies are not perfectly observable, the mechanism creates a phenomenon of adverse selection. In such a situation, a low liquidity shock can cause deterioration in the quality of all financial institutions that have no liquidity, prompting further liquidity to the holders of not relinquish. Such behavior raises questions about the respective roles and tools of central banks, banks and other financial institutions with regard to creating and maintaining deep and liquid markets.

\subsection{Capital shortage}

Since the beginning of the financial turmoil, banks have faced mounting pressure on their balance sheets. On the credit side of the balance sheet, securitization or syndication of assets has left banks with large volumes of loans that were about to be transferred when the crisis erupted. The limited ability of markets to absorb the securitized assets has sharply reduced the ability of banks to transfer assets and risks off their balance sheets. At the same time, assets that had previously been transferred off the balance sheet had to be reinstated because of credit risk, liquidity and reputation. In fact, banks are vulnerable to allegations that they did not check borrowers adequately or properly warned investors of the risks of the securitized products they had. The management of reputation risk has played a key role in the decision of banks to support the pipes that they had sponsored or taken part in their restructuring, even in the absence of any legal obligation. As regards the liabilities of banks, the effects of recovery are affected capital reserves through the losses on stocks. Meanwhile, the cost of bank funding has increased and conditions for raising new capital 
have tightened. Regarding equity, the sharp decline in market capitalization of banks increased the cost of capital. Signs of lack of capital have also made outside the banking sector. The monoline insurers loans, which are major counterparties and banks who sell credit protection on the senior and super senior tranches of RMBS and CDOs, have also suffered heavy losses in market value.

\section{Policy responses and agenda to restore the smooth functioning of capital markets}

\subsection{Adapting regulation}

In the short term, some shortcomings must be addressed without necessarily lead to additional regulations. First, because many initiatives are linked to corrective management decisions purely domestic financial institutions. Then, because the scope of regulation is first and foremost provide the right incentives to improve market efficiency. This may require minor adjustments in capital requirements or for recovery, but nothing more. Strict regulations may indeed be a powerful engine of financial innovation, designed specifically to circumvent and render quickly made obsolete. In addition, the liquidity regulation cannot be implemented too mechanical; the liquidity requirement may not correspond to usable liquidity.

\subsection{Improving information and transparency}

One of the main features of the credit market is that it is not perfect. Problems of moral hazard and adverse selection are parts of the current upheaval resulting from the presence of asymmetric information. In this area, improving information and transparency is a means of restoring confidence. The gradual implementation of Basel II from 2008 would have had to bring some answers to these problems, particularly with regard to regulated entities. Furthermore, the role and extent of liquidity risk should be better recognized and taken into account in regulatory requirements. This requires for example to take account of liquidity risk in the crisis simulation exercises. Similar efforts should also be made in respect of unregulated entities. Liquidity risk is intrinsically linked to other risks identified in the recent period of financial turmoil: market risks, credit risks and reputation risks. Mastering all of these risks in a transparent environment is an important step to prevent the liquidity is hoarded and thus restores confidence.

\subsection{Improve operational frameworks for the provision of central bank liquidity}

The considerations of moral hazard in the context of a liquidity crisis are a reflection pattern for central banks. During the crisis, the latter have done their job by responding to an exogenous increase and widespread demand for base money and ensuring a smooth adjustment of liquidity conditions. However, conducting monetary policy actions in a world disintermediated raises additional difficulties. The main refinancing needs can indeed come from nonbank financial institutions that do not have direct access to central bank reserves. Some of them are also regulated. As noted above, an important source of liquidity and credit emanates over one of the banking systems and should be recognized that the control of central bank liquidity is at once indirect and probably limited. In illustration of this point the financial turmoil has shown that if the monetary aggregates and credit, that is to say the liquidity intermediated by banks, have so far continued to grow at a rapid pace, others elements of liquidity, such as outstanding commercial paper backed by assets were, however, strongly contracted. This creates a potential dilemma for monetary policy. During the crisis, some central banks had to adapt their operational frameworks by extending the duration of their operations or expanding the list of assets eligible for refinancing operations. Further improvements could be on the agenda to improve the robustness of these devices. 


\subsection{Refine risk assessment to improve the external rating}

Regulating rating agencies would possibly be an option. However, in the context of the implementation of Basel II, the rating process will inevitably play a pivotal role involving a refinement in the assessment of risks throughout the promotion of internal models and greater use of external ratings. To the extent that rating agencies are producing a public good in providing information on the quality of assets underlying transactions or risk exposure and constitute a key element in the marketability of structured products, some improvements can be considered. There are two areas, among others, that could deserve consideration for the future: first, greater transparency of rating methods and the overall role of rating agencies in the securitization process. Second, a marked difference in the metric used for rating bonds and structured products, which would be a key condition to restore confidence in ratings. This could be done in two ways, which could also be combined: either by adopting another rating scale for structured products (with another symbol for example); or by including an additional measure in the credit rating, in particular on its volatility in times of market or liquidity stress.

\subsection{Strengthening the capital framework}

Finally, the recent financial turmoil has evidenced that increasing risk taking with a shrinking proportion of capital is not sustainable. It is even more the case in the context of fair value accounting where depreciation each immediately impacts on capital. Ultimately, the ability of an investor to carry risk is determined by her capital base. And capital should act as a buffer, i.e. it must be sufficient to absorb shocks. To some extent, the crisis has pointed out a profound failure on the part of leading banks to understand how their on and off-balance sheet exposures interact together and with their capital. Is it therefore desirable to ask for increased capital buffers to banks, other financial intermediaries and off-balance sheet structures involved in risk transfer? This could draw upon the experience of the hedge fund industry where some devices like lock-up periods exist and have proved helpful in the current turmoil to stabilize their resources. More severe capital constraints could help to curb excessive leverage in the financial system. However, these stricter requirements should not destroy all incentives to use securitization. Higher capital buffers should be conceived not so much to absorb all potential risks (they would never be sufficient for that), but to act as a disincentive to excess risk taking. A possible solution could be to use the flexibility within Basel II framework, in particular including its Pillar 2, to ensure that capital buffers are adequately forward-looking. Another more complex solution was already drafted a new agreement being associated Basel.

\section{Future of the regulation - Basel III}

The Group of Governors and Heads of Supervision ${ }^{3}$, the oversight body of the Basel Committee on Banking Supervision, met on 26 July 2010 to review the Basel Committee's capital and liquidity reform package. Governors and Heads of Supervision are deeply committed to increase the quality, quantity, and international consistency of capital, to strengthen liquidity standards, to discourage excessive leverage and risk taking, and reduce pro-cyclicality. Governors and Heads of Supervision reached broad agreement on the overall design of the capital and liquidity reform package. In particular, this includes (a) the definition of capital, (b) the treatment of counterparty credit risk, (c) the leverage ratio, and (d) the global liquidity standard.

\footnotetext{
${ }^{3}$ The Group of Central Bank Governors and Heads of Supervision is the governing body of the Basel Committee and are comprised of central bank governors and (non-central bank) heads of supervision from member countries. The Committee's Secretariat is based at the Bank for International Settlements in Basel, Switzerland. The Basel Committee on Banking Supervision provides a forum for regular cooperation on banking supervisory matters. It seeks to promote and strengthen supervisory and risk management practices globally. The Committee comprises representatives from Argentina, Australia, Belgium, Brazil, Canada, China, France, Germany, Hong Kong SAR, India, Indonesia, Italy, Japan, Korea, Luxembourg, Mexico, the Netherlands, Russia, Saudi Arabia, Singapore, South Africa, Spain, Sweden, Switzerland, Turkey, the United Kingdom and the United States.
} 
The key broad agreements of the Governors and Heads of Supervision are given below the structure already mentioned.

\subsection{Improving the quality and consistency of regulatory capital}

A primary goal of the Basel Committee is to increase the quality and global consistency of regulatory capital and to standardize the required deductions and adjustments. It intends that Tier 1 capital should enable each bank to remain a going concern, with Tier 2 capital re-categorized as a "gone concern" reserve to protect depositors in the event of insolvency, and Tier 3 capital abolished altogether. In addition, it states that Tier 1 capital should predominantly comprise common equity and retained earnings, with a tighter definition of common equity. The Basel Committee proposes the introduction of much stricter criteria on the inclusion of hybrid instruments, notably the requirement for coupons to be noncumulative and fully discretionary and for principal to be available to absorb losses on an ongoing basis, either through principal write-down or conversion into common equity.

The Basel III proposals are likely to make hybrid Tier 1 capital more equity-like and homogeneous, with a higher likelihood of coupons on future hybrids being cancelled in periods of stress. Furthermore, the Basel Committee proposes to phase out so-called innovative Tier 1 instruments with embedded incentives to redeem, such as coupon step-ups. Overall, investors in hybrids eligible within future Tier 1 capital are expected to bear more risks, both in terms of loss absorption and the potential absence of redemption.

It is welcoming the proposal to strengthen and simplify the capital structure of banks. Recent experience has shown that the co-existence of multiple classes of regulatory capital instruments has sometimes had unintended consequences in terms of the flexibility to defer coupons and the predictability of banks' behavior. Furthermore, some regulatory capital instruments such as no deferrable Tier 2 and Tier 3 issues had minimal equity content, and therefore we have not included them in our capital measures.

The consultative document lists a number of items that must be adjusted for in common equity, including minority interests in consolidated subsidiaries, unrealized losses on balance sheet assets, cash flow hedge reserves, goodwill and other intangibles, net tax loss carry forwards, defined-benefit pension fund deficits, investments in unconsolidated subsidiaries such as insurance businesses, and any shortfall in loan loss provisions relative to expected losses. The proposals also call for improved disclosure of regulatory capital calculations to enhance transparency and aid reconciliations with accounting data.

The proposals represent a significant tightening and harmonization of regulatory capital requirements. It appears, for example, that few existing Tier 1 hybrid instruments would qualify for continued inclusion in Tier 1, absent a grandfathering arrangement. In addition, the list of capital adjustments is more comprehensive than the rules currently applied of any major national regulator. The proposal that these items should be deducted from common equity rather than a broader capital measure is very exacting. However, it addresses one of the weaknesses of the current regime, where capital needs of certain activities, particularly nonbanking businesses such as insurance, were partly or entirely covered by subordinated debt which did not absorb losses on a going-concern basis. Given the complexity of capital requirements for financial conglomerates, it remains to be seen if this more demanding rule will be implemented in a consistent manner in all jurisdictions. The required Basel III deductions would likely have a significant impact on most banks, with certain institutions and sectors particularly affected.

The full consequences of these definitional changes cannot be accurately quantified until the Basel Committee has determined the minimum capital ratios that banks must maintain. It was undertaking an impact study during the first half of 2010 to calibrate the required minima, which would be applied at three different levels (common equity, Tier 1, and total regulatory capital). Since the effect of the Basel III proposals is likely to be material, it is expected an extended 
transition period, significant grandfathering of existing capital instruments, and/or other regulatory adjustments to ease the impact on the sector and the wider economy. Still, the banking industry might well need to conserve capital--through constrained dividends, for example--and some institutions might decide to adapt their business models--through selected disposals, for example--in response to the new rules.

\subsection{Counterparty credit risk}

The Basel III proposals contain a number of measures that would significantly raise capital requirements for trading-related counterparty risks. These changes are intended to address deficiencies in the Basel II methodology that were highlighted by the recent period of acute market volatility. In summary, the proposals in the Basel III consultative document call for: the use of stressed inputs in the calculation of potential future counterparty exposures; the introduction of a capital charge against potential mark-to-market losses arising from deteriorating counterparty creditworthiness short of actual default; an increase in the correlation assumptions for exposures to other financial institutions, with embedded incentives to move over-the-counter (OTC) trading to central counterparties and exchanges; and increased capital charges in certain other areas, such as wrong way risk (which arises when the probability of default and the exposure at default are positively correlated, as banks experienced, for example, in the case of asset-backed securities hedged with monolines).

The proposed strengthening of the counterparty risk capital charge would have the greatest impact on banks with large capital markets activities. It is estimate that the counterparty risk charge could increase very significantly from the current level, with the main driver being the proposed introduction of a Pillar 1 value-at-risk charge on counterparty valuation adjustments. In general, we consider that the proposed changes are a reasonable response to recent events.

The assessment of asset correlation between financial institutions had indicated that the levels assumed in Basel 2 (12\%-24\%) were too low in times of stress. The potential implications for the smooth functioning of the interbank market require further consideration, however. Although we agree with the underlying concepts, we see calibration issues with the Pillar 1 value-at-risk charge on credit valuation adjustments.

The Committee is making the following modification to the treatment of counterparty credit risk, including the bond equivalent approach to calculating the credit valuation adjustment (CVA): (1) Modify the bond equivalent approach to address hedging, risk capture, effective maturity and double counting; (2) Keep the asset value correlation adjustment at $25 \%$ to reflect the inherent higher risk of exposures to other financial entities and to help address the interconnectedness issue, but raise the threshold from $\$ 25$ billion to $\$ 100$ billion; and (3) Banks' mark-to-market and collateral exposures to a central counterparty (CCP) should be subject to a modest risk weight, for example in the 1-3\% range, so that banks remain cognizant that CCP exposures are not risk free.

More advanced alternatives to the bond equivalent approach could be considered as part of the fundamental review of the trading book.

\subsection{Leverage ratio}

Leverage ratios are already applied to banks in certain countries, such as the U.S., and other national regulators, such as Switzerland's FINMA, have announced plans to introduce similar measures as a response to the recent crisis.

The Basel III proposals would introduce a consistent leverage ratio measure for all internationally active banks. The consultative document indicates that this measure would initially be a Pillar 2 monitoring tool, but could ultimately become a Pillar 1 requirement. The document sets out a number of options for the calculation of the numerator and denominator of the ratio. Both are positioned relatively conservatively in our opinion. The numerator is intended to be a high quality capital measure, which suggests that it will be either common equity or Tier 1. For the denominator, 
the consultative document indicates that netting of repurchase agreement (repo) and derivative contracts might not be recognized. For many banks, this would make a substantial difference to the leverage ratio outcome, similar to the existing balance sheet gross-up under International Financial Reporting Standards (IFRS) relative to U.S. generally accepted accounting principles (GAAP). The Basel Committee will also consider whether to include short credit derivative positions and several off-balance-sheet items at their notional values, which would also have a significant impact in many cases.

The objective is to develop a simple, transparent, non-risk based measure that is calibrated to act as a credible supplementary measure to the risk based requirements. It is agreed on the following design and calibration for the leverage ratio, which would serve as the basis for testing during the parallel run period: (1) For off-balance-sheet (OBS) items, use uniform credit conversion factors (CCFs), with a 10\% CCF for unconditionally cancellable OBS commitments (subject to further review to ensure that the $10 \% \mathrm{CCF}$ is appropriately conservative based on historical experience); (2) For all derivatives (including credit derivatives), apply Basel II netting plus a simple measure of potential future exposure based on the standardized factors of the current exposure method. This ensures that all derivatives are converted in a consistent manner to a "loan equivalent" amount; (3) the leverage ratio will be calculated as an average over the quarter. Taken together, this approach would result in a strong treatment for OBS items. It would also strengthen the treatment of derivatives relative to the purely accounting based measure (and provide a simple way of addressing differences between IFRS and GAAP).

When it comes to the calibration, the proposing is to test a minimum Tier 1 leverage ratio of $3 \%$ during the parallel run period. It will use the transition period to assess whether the proposed design and calibration is appropriate over a full credit cycle and for different types of business models. This assessment will include consideration of whether a wider definition of exposures and an offsetting adjustment in the calibration would better achieve the objectives of the ratio.

While there is a strong consensus to base the leverage ratio on the new definition of Tier 1 capital, also will be track the impact of using total capital and tangible common equity.

\subsection{Global liquidity ${ }^{4}$ standard}

Governors and Heads of Supervision also agreed on the Basel Committee's concrete proposals to recalibrate the stress scenarios to achieve a conservative bank level and plausibly severe system wide shock. The Committee also made revisions to the definition of qualifying liquid assets subject to the overall requirement that such assets remain prudently liquid in periods of stress. The goal is to achieve a calibration and definition that penalizes imprudent liquidity profiles, while minimizing system level distortions. The Committee will review the impact of these changes to ensure that they deliver a rigorous overall liquidity standard.

The Basel Committee published a separate consultative document regarding new international standards for liquidity management and monitoring. Specifically, the document proposes two complementary metrics that are intended to encapsulate banks' short-term liquidity and structural funding positions:

- The short-term liquidity metric - named the liquidity coverage ratio (LCR) in the consultative document - would require banks to maintain high quality, unencumbered assets in excess of their stressed cash outflows over a 30-day time horizon. The document proposes several possible definitions of the numerator and denominator, including the haircuts to be applied to eligible liquid assets and the stressed outflow assumptions for each category of liabilities and off-balance-sheet commitments.

- The structural funding metric - named the net stable funding ratio (NSFR) - effectively assesses the behavioral maturity of each side of the balance sheet over a one-year horizon. More

\footnotetext{
${ }^{4}$ Liquidity describes a market on which transactions do not provoke strong price fluctuations.
} 
particularly, haircuts are applied to each category of assets and liabilities according to their expected stability through a stress scenario, and the available stable funding must exceed the required stable funding.

The proposed introduction of internationally-consistent minimum liquidity standards represents a positive step. The time horizon assumed in each ratio as relatively could be short, however, particularly for more highly rated institutions, which we would expect to target a longer survival period. The 30-day horizon used in the liquidity coverage ratio appears to have been borrowed from the established stress test standard for U.S. broker dealers. Although we believe this ratio would provide a better basis to compare banks than existing published liquidity metrics, the prolonged liquidity crunch of late 2008 and early 2009 demonstrates that financial institutions need to be able to function in a stress scenario for longer than 30 days. The consultative document proposes other monitoring tools to assess liquidity over different time horizons, but it is unclear whether these would be applied as consistently as the liquidity coverage ratio. We also consider that the categories put forward in the consultative document for banks' liquidity sources and uses have not yet been precisely defined, and could usefully be more granular and nuanced. The chosen definition of liquid assets could lead to distortions in the markets for eligible and non-eligible securities.

The consultative document does not make firm recommendations on important practical aspects of the proposed liquidity regime, such as the frequency of calculation, the depth of public disclosure, and the scope of application. For example, the document indicates that banks would report only on a consolidated basis, which might not be sufficient for large, global banks with major liquidity requirements in multiple currencies and regions. Although we would not advocate a regulatory regime which required banks to lock up material liquidity pools in individual jurisdictions, thereby constraining the fungibility of resources across each group, we believe that banks should demonstrate that they can channel funds to individual legal entities on a timely basis.

\subsection{Transparency}

There is a strong improvement in transparency and the emphasis placed on market discipline in the various elements of the Basel III proposals. The Basel Committee's view is that the disclosure provided by banks regarding regulatory capital measures has frequently been deficient to date. The proposals would notably require a published reconciliation of regulatory capital measures to the financial statements, the separate disclosure of all regulatory adjustments, the identification of all limits applied, and the description of the main features of hybrid capital instruments. The committee intends to require rigorous Pillar 3 disclosures on other components of the proposals, such as the computation of the leverage ratio.

Given the differences in accounting treatments across jurisdictions, for instance between IFRS and U.S. GAAP, it is supportive of these additional disclosures that would facilitate comparison of financial metrics between jurisdictions.

\section{Conclusions}

Finally we identify the main hallmarks of the crisis as:

- Too-big-to-fail institutions that took on too much risk - a large part of these risks being driven by new innovations that took advantage of regulatory and tax arbitrage with no effective constraints on leverage.

- Insolvency resulting from contagion and counterparty risk, driven mainly by the capital market (as opposed to traditional credit market) activities of banks, and giving rise to the need for massive taxpayer support and guarantees. Banks simply did not have enough capital.

- The lack of regulatory and supervisory integration, which allowed promises in the financial system to be transformed with derivatives and passed out to the less regulated and capitalized 
industries outside of banking - such as insurance and re-insurance. The same promises in the financial system were not treated equally.

- The lack of efficient resolution regimes to remove insolvent firms from the system. This issue, of course, is not independent of the structure of firms which might be too-big-to-fail. For example, some might have great difficulty resolving some financial institutions given their size relative to the economy. They may have less trouble resolving a failed legally separated subsidiary.

How do the Basel III proposals bear on these issues, in the sense of helping to ensure that the chance of another crisis like the current one can be greatly reduced? The Basel III capital proposals have some very useful elements - notably the support for a leverage ratio, a capital buffer and the proposal to deal with pro-cyclicality through dynamic provisioning based on expected losses. Adopting the buffer capital proposal to ensure the leverage ratio was not compromised in crisis situations seems especially important - so that in good times, dividends, share buyback policies and bonuses would be restrained as necessary to build back buffers used up in bad times seems very important.

These can easily be incorporated with other future reforms.

\section{References}

1. Banque de France, 2010. De la crise financière à la crise économique, Documents and debates, No. 3, January

2. Blundell-Wignall, A., et al., 2009. The Elephant in the Room: The Need to Deal with What Banks Do, OECD Journal: Financial Market Trends, vol. 2009/2

3. Blundell-Wignall, A., Atkinson, P., 2010. Thinking Beyond Basel III: Necessary Solutions for Capital and Liquidity, OECD Journal: Financial Market Trends vol. 2010/1

4. BCBS - Basel Committee on Banking Supervision, 1988. International Convergence of Capital Measurement and Capital Standards, July

5. BCBS -- Basel Committee on Banking Supervision, 2004. International Convergence of Capital Measurement and Capital Standards: A Revised Framework, June

6. BCBS -- Basel Committee on Banking Supervision, 2006. International Convergence of Capital Measurement and Capital Standards: A Revised framework - Comprehensive Version, June

7. BCBS - Basel Committee on Banking Supervision, 2009a. Revisions to the Basel II Market Risk Framework, consultative document, January

8. BCBS - Basel Committee on Banking Supervision, 2009b. Analysis of the Trading Book Impact Study, October

9. FDIC - Federal Deposit Insurance Corporation 2005. Capital and Accounting News....Basel II and the Potential Effect on Insured Institutions in the United States: Results of the Fourth Quantitative Impact Study (QIS-4), Supervisory Insights, winter, pp. 27-32

10. Goodhart, C., 2010. Liquidity risk management, Financial Stability Review, No. 11, Banque de France, February

11. Gordy, M.B., 2003. A Risk-Factor Model Foundation for Ratings-Based Bank Capital Rules, Journal of Financial Intermediation, vol. 12

12. Jackson, P., 1999. Capital Requirements and Bank Behavior: The Impact of the Basle Accord, Basle Committee on Banking Supervision Working Papers, No. 1, April

13. Kane, E.J., 2006. Basel II: a Contracting Perspective, NBER Working Papers, 12705, November

14. OECD, 2009. The Financial Crisis: Reform and Exit Strategies, September, OECD, Paris, available at www.oecd.org/dataoecd/55/47/43091457.pdf.

15. Sorkin, A. R., 2010. New York Times, issue 17 March

16. Standard \& Poor's Financial Services of the McGraw-Hill Companies, 2010. Response to the Basel Committee's Proposals on Bank Capital And Liquidity, April 